\begin{tabular}{|c|c|}
\hline \multirow{3}{*}{ 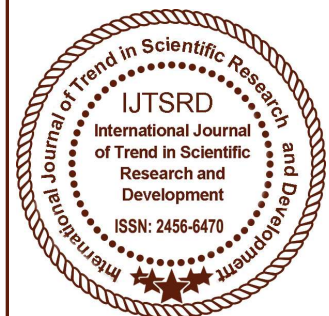 } & $\begin{array}{l}\text { International Journal of Trend in Scientific } \\
\text { Research and Development (IJTSRD) }\end{array}$ \\
\hline & International Open Access Journal \\
\hline & ISSN No: 2456 - 6470 | www.ijtsrd.com | Volume - 2 | Issue - 1 \\
\hline
\end{tabular}

\title{
An Analysis of The Relationship Between Organizational Commitment and Occupational Stress (A Study with Special Reference to Selected Hospitals in Pune City)
}

\author{
Jyothi Pawar \\ Assistant Professor, Sinhgad Institute of \\ Management, Pune
}

\author{
Dr. S. V. Shrigiriwar \\ Assistant Professor, Sinhgad Institute of \\ Management,Pune
}

\section{ABSTRACT}

Organizational commitment is widely illustrated in the organizational management. The level of commitment strongly influences the retention level of workforce and affects employee work performance. It is the key factor in the relationship between individual and organization. Stress caused due to a person's work or employment is termed as occupational stress. Occupational stress is the harmful physical and emotional responses that occur when the requirements of the job do not match the capabilities, resources, or needs of the worker.

The paper focuses on the level of stress being found among Employees working in the Government and Private hospitals in Pune and relationship with their work commitment. The study revealed that occupational stress has a statistically significant negative effect on organizational commitment. Commitment scores were negatively correlated with stress and sources of work stress. This was particularly evident in relation to role ambiguity, work relations, and work system stresses. At the end of the paper the authors made a modest attempt to suggest some workable strategies to minimize the level of stress and finally increase the level of commitment.

Keywords: Organizational commitment, work performance, Stress, Occupational stress.

\section{Introduction:}

Employees' commitment to their organization is indispensible to the success of organization because uncommitted employees don't pay attention to their work and consequently it leads to poor performance. High level of organizational commitment culminates in high level of work efforts and high performance because both variables were positively related to each other. Besides, low level of commitment to organization gives rise to high absenteeism and high employees' turnover intention that ultimately culminates in actual turnover.

Organizational commitment and Occupational stress have long been concern for employees because of the impact and influence they have on work. In today's world, stress has become a worldwide phenomenon, which is virtually there in some form in every workplace. The reason could be working life; employees are generally working for longer hours, as the rising levels of responsibilities require them to exert themselves even more strenuously to meet rising expectations about work performance.

Organizational commitment is widely illustrated in the organizational management. The level of commitment strongly influences the retention level of workforce and affects employee work performance. It is the key factor in the relationship between individual and organization. 


\section{Occupational Stress}

Stress caused due to a person's work or employment is termed as occupational stress. Occupational stress is the harmful physical and emotional responses that occur when the requirements of the job do not match the capabilities, resources, or needs of the worker.

\section{Organizational Commitment}

Organizational commitment can take a variety of forms and has the potential to power Organizational effectiveness and employee well-being. Organizational commitment is defined as an employee's level of identification and involvement in the organization. A review of the text on organizational commitment exposed that the earliest concept of organizational commitment originated from research work it is found that, an individual's choice to join an organization is based on the conviction that the organization can fulfill a personal require and if there is an imbalance between inducements and contributions, the individual may leave system. organizational effectiveness is dependent on individuals' commitment to cooperate in furthering the organizational goals. Therefore, maintaining the commitment of individuals is very important to an effective organization.

It is proved by many of the study that there is relationship between organizational commitment and occupational stress. These studies point to that continued interest is the result of the belief that if properly managed, employee's organizational commitment can lead to valuable consequences such as organizational success, reduced employee turnover and low absenteeism. An extensive reviewing revealed that a great deal has been written about the causes and adverse effects of occupational stress as well as the importance of organizational realization of individual professional goal \&organizational goals. However a study which could address the relationship between organizational commitment and occupational stress in hospitals in Pune city has not been conducted. The problem to be investigated is to examine the relationship between occupational stress and occupational commitment in hospitals in Pune.

Further this study aims to explain the level, causes and dimensions of occupational stress and the level and forms of organizational commitment of employees in hospitals in Pune city.

\section{Research Objectives}

1) To determine the relationship between organisational commitment and occupational stress.

2) To find out the level, causes and dimensions of occupational stress among the employees who are working in the hospitals in Pune using appropriate measuring instrument.

3) To explore the level and forms of organizational commitment.

4) To analyse and ascertain the affects of various demographic variables including age, qualification income and marital status on the occupational stress and Organizational commitment of employees.

\section{Hypotheses:}

- H1:-There is an inverse relationship between occupational stress and occupational commitment.

- H2:-Private hospitals employees experience more of stress compared to government hospitals employees, mainly due to their occupational roles and demands which leads to high personal strain.

- H3:-Experienced employees experience less occupational stress than less experienced hospital employees.

- H4:- The level of organizational commitment of hospitals (Government-Private) employees increases with age, experience, income and job position.

\section{Research Methodology:}

- Research Design: - Descriptive and Quantitative research has been used for the purpose of the study.

- Sampling Design: - The sampling plan for the research is as follows,

- Population: -Government and Private Hospitals.

- Sample: - Employees working in the Government and Private hospitals

- Sample frame: - Pune city.

- Sample size:-10\% of the population to the maximum size of 1000 respondents.(IMA) 
International Journal of Trend in Scientific Research and Development (IJTSRD) ISSN: 2456-6470

- Sampling technique: - Simple Random sampling technique.

- Sources of data and tools:-Data has been collected from both the secondary as well as Primary sources for the purpose of the study.

- Primary data:-The primary data has been collected by in depth interview with the help of Pre-tested Structured questionnaire for organizational commitment using the 5 point likert scale (i.e. OCQ) and OSIat the very same time observation method will be adopted as a supplementary technique to generate more thoughtful information about the research topic at hand.

- Secondary data: - has been collected through various sources like Books, Magazines, Newspapers, Journals, Various websites.

- Pre-test of the questionnaire: - Questionnaire has been pre-tested among 25 respondents; this will facilitate modification, in the questionnaire and subsequently the interview for the purpose of data collection.

- Processing of Data: - In the present research work data relative to respondent's opinion has been processed using SPSS and MS Excel.

- Methods of analysis and statistical tool: - Since the present study is basically descriptive, hence the researcher has employed tabular analysis, percentage analysis, and graphical Analysis to analyze the data for studying the different objectives.

\section{Result and Discussions:}

\section{Hypothesis 1}

H0: There is no significant Correlation between sources of work stress and commitment and domain of occupational stress

H1: there is a significant Correlation between sources of work stress and commitment and domain of occupational stress

\begin{tabular}{|l|c|c|c|c|}
\hline \multicolumn{1}{|c|}{$\begin{array}{c}\text { Occupational stress } \\
\text { domains }\end{array}$} & \multicolumn{2}{c|}{$\begin{array}{c}\text { Job sources of } \\
\text { work stress }\end{array}$} & \multicolumn{2}{c|}{$\begin{array}{c}\text { Organizational } \\
\text { commitment } \\
\text { p-value }\end{array}$} \\
\hline Role ambiguity & r & p-value & R & p-val \\
\hline Work Relations & 0.52 & $<0.001^{*}$ & -0.18 & $0.03^{*}$ \\
\hline Work Environment & 0.59 & $<0.001^{*}$ & -0.18 & $0.03^{*}$ \\
Resources & 0.42 & $<0.001^{*}$ & -0.15 & 0.06 \\
\hline Family-related & 0.09 & 0.25 & 0.15 & 0.06 \\
\hline Workload & 0.31 & $<0.001^{*}$ & -0.15 & 0.06 \\
\hline Personality & 0.16 & 0.06 & -0.07 & 0.42 \\
\hline Professionalism & 0.52 & $<0.001^{*}$ & -0.15 & 0.07 \\
\hline Work system & 0.53 & $<0.001^{*}$ & -0.14 & 0.08 \\
\hline Total stress & 0.48 & $<0.001^{*}$ & -0.23 & $0.004^{*}$ \\
\hline
\end{tabular}

(*) Statistically significant at $\mathrm{p}<0.05$.

The correlation between each of the sources of work stress and commitment scores and the domains of occupational stress scores is shown in above table. It points to statistically significant positive weak to 
moderate correlations between sources of work stress scores and almost all occupational stress domains. The only exceptions were the domains of resources and workload, which were not statistically significant.

Conversely, negative weak statistically significant correlations were revealed between organizational commitment scores and only three of the occupational stress domains, namely role ambiguity $(\mathrm{r}=-0.18$, $\mathrm{p}=0.03)$, work relations $(\mathrm{r}=-0.18, \mathrm{p}=0.03)$, and work system $(\mathrm{r}=-0.23, \mathrm{p}=0.004)$.

The table also indicates that total stress scores were statistically significantly and positively correlated with sources of work stress $(\mathrm{r}=0.61, \mathrm{p}<0.001)$.
Meanwhile, the correlation between organizational commitment scores and stress scores was negative and statistically significant $(\mathrm{r}=-0.18, \mathrm{p}=0.025)$.

\section{Hypothesis 2:}

H0: There is no significant Correlation between coping strategies and physical health and domains of occupational stress

H0: There is significant Correlation between coping strategies and physical health and domains of occupational stress

\begin{tabular}{|l|c|c|c|c|}
\hline \multirow{2}{*}{ Job stress domains } & \multicolumn{2}{|c|}{ Coping strategies } & \multicolumn{2}{c|}{ Physical health } \\
\cline { 2 - 5 } & $\mathbf{R}$ & p-value & $\mathbf{R}$ & p-value \\
\hline Role ambiguity & 0.35 & $<0.001^{*}$ & 0.25 & $0.002^{*}$ \\
\hline Work Relations & 0.39 & $<0.001^{*}$ & 0.18 & $0.03^{*}$ \\
Work Environment & 0.16 & $0.049^{*}$ & 0.13 & 0.11 \\
\hline Resources & 0.06 & 0.47 & 0.03 & 0.73 \\
Family-related & 0.23 & $0.005^{*}$ & 0.10 & 0.21 \\
\hline Workload & -0.03 & 0.76 & 0.02 & 0.77 \\
\hline Personality & 0.27 & $0.001^{*}$ & 0.11 & 0.17 \\
\hline Professionalism & 0.32 & $<0.001^{*}$ & 0.20 & $0.01 *$ \\
\hline Work system & 0.23 & $0.005^{*}$ & 0.12 & 0.16 \\
\hline
\end{tabular}

(*) Statistically significant at $\mathrm{p}<0.05$.

The above table demonstrates the correlation between coping strategies and physical health scores, from one side, and the scores of various domains of occupational stress, from the other side. From the table, it can be noticed that there are statistically significant positive weak correlations between coping strategies scores and most of the occupational stress domains. The only exceptions were the domains of resources and workload, which were not statistically significant. As for the scores of the physical health, the table indicates weak statistically significant positive correlations with role ambiguity $(\mathrm{r}=0.25$, $\mathrm{p}=0.02)$, work relations $(\mathrm{r}=0.18, \mathrm{p}=0.03)$, and professionalism $(\mathrm{r}=0.20, \mathrm{p}=0.01)$.

\section{Findings and Recommendations:}

- Employees are exposed to stressors such as staffing level, administrative duties, and over workload sources of stress.

- Similarly work condition, poor staffing, poor staff cohesiveness, shift work, low staffing levels and restructuring initiatives had contributed to the stress.

- Another finding is that the non supportive work environment, role ambiguity, family-related, personal characteristics and professionalism are 
occupational stressors that have been suggested as factors contributing to sources of work stress.

- Commitment scores were negatively correlated with stress and sources of work stress. This was particularly evident in relation to role ambiguity, work relations, and work system stresses.

- This means that the more these stresses and/or sources of work stresses are felt, the less the staff are committed to their jobs.

- The lack of such stressors at work is certainly associated with a higher level of job satisfaction, which is an important determinant of organizational commitment.

- Moreover, it is also observed that organizational commitment is affected by sources of stress such as workload, conflict, and work relationships.

- Further, occupational stress has a statistically significant negative effect on organizational commitment. Finally, it was found that commitment scores were high for most executives, and were correlated inversely with occupational stress.

- Organizational commitment protects the individual from negative outcomes experienced at work

- Physical health has statistically significant positive correlations with stresses related to role ambiguity, work relations, and professionalism.

- appropriate recruitment strategies

- Since work environment and personal characteristics contributed to occupational stress and organizational commitment, staff should be able to assess these factors and give each other support in order to improve performance

- Healthcare organizations should identify factors that contribute to sources of work stress and identify the various conditions that bring staff into the work using appropriate coping strategies and providing clear and specific job description, flexible work schedules, fair treatment and regular meeting between supervisors and their staff to discuss and solve their problem.

- Both staff and administrators particularly doctors must be willing to work together to develop a climate of mutual trust that fosters a genuine commitment to organizational goals, to provide quality patient care.

\section{Conclusion:}

Since work environment and personal characteristics contributed to occupational stress and organizational commitment, staff should be able to assess these factors and give each other support in order to improve performance. Organizations should identify factors that contribute to sources of work stress and identify the various conditions that bring staff into the work using appropriate coping strategies and providing clear and specific job description, flexible work schedules, fair treatment and regular meeting between supervisors and their staff to discuss and solve their problem. Both staff and administrators particularly doctors must be willing to work together to develop a climate of mutual trust that fosters a genuine commitment to organizational goals, to provide quality patient care. Further studies are necessary to identify and clarify the specific coping strategies used by staff, and to increase understanding regarding the relationship between the experience of stress and the effects of stress.

\section{REFERENCES:}

1) Anderson P. and Pulich M., 2001, "Managing Work Places Stress in a Dynamic Environment", Healthcare Managers, 19(3), Pp.: 1-10.

2) Braaten Dan J., 2000, "Occupational Stress in Mental Health Counsellors", University of Wisconsin-Stout.

3) Colligan Thomas W and Higgins Eileen M., 2006, "Workplace Stress-Etiology and consequences", Journal of Workplace Behavioural Health, Vol.: 21(2), Pp.: 89-97.

4) Colligns Thomas W. and Higgins Eileen M., 2005, "Workplace Stress: Etiology and

5) Consequences", Journal of Workplace Behavioural Health, Vol.: 21(2), Pp.: 1-10.

6) Costa G., 1996, “The Impact of Shift and Night Work on Health", Applied Ergonomics, 27(1), Pp.: 9-16.

7) Cristiana Catalina Cicei (2011) Occupational stress and organizational commitment in Romanian public organizations, Procedia - Social and Behavioral Sciences 33 (2012) 1077 - 1081, Available online at www.sciencedirect.com 
8) Edwards and Burnard P., 2003, "A Systematic Review of Stress and Stress Management Interventions for Mental Health Nurses", Journal of Advanced Nursing, 42, Pp.: 169-200.

9) EdwardsD., HanniganB., Fothergill A.and BurnardP., 2002 "Stress Management for Mental Health Professions: A Review of Effective Techniques", Society for the Investigation of Stress, Vol.: 18, Pp.: 203-215.

10) Israel B., House J., Schurman S., Heane C., and Mero R., 1989 "Relation of Personal Resources, Participation, Influence, Interpersonal Relationship and Coping Strategies to Occupational Stress, Job Strains and Health: A Multi-Variate Analysis", Work Stress, 3, Pp.: 169194.

11) Ladegard Gro, 2011, "Stress Management through Workplace Coaching: The Impact of Learning Experiences", International Journal of Evidence based Coaching and Monitoring, Vol.: 9, No.: 1, Pp.: 29.

12) Lamb B., 1984," Physiology of Exerciser: Response and Adaptions, McMillian, New York, N. Y.

13) Lazarus R. and Folkman S., 1984, "Stress, Appraisal and Coping”, New York: Springer.

14) Lepiine J. A. and Jackson C. L, 2004, “Challenge and Hindrance Stress: Relationship with Exhaustion, Motivation to learn and Learning Performance", Journal of Applied Psychology, Pp.: 883-891.

15) Michie Dr. Susane, 2002, "Causes and Management of Stress at Work", International Journal of Occupational and Environmental Medicine, 59: 7i:10.1136/OEM.59.1.67, Pp.: 6772.

16) Moomuang Nikom, 2005; "Stress Management and Health Promotion Behaviours in Young Men in Tertiary Education Settings", Thesis, Pp.: $7,162,185$.

17) Murphy L. R., 1995, “Occupational Stress Management: Current Status and Future

18) Directions", Trends in Organisational Behaviour, 2, Рp.: 1-14.

19) Nazim Ali \& Shahid Jan Kakakhel (2013)Relationship between Occupational Stress and Organizational Commitment (Empirical
Evidence from Pharmaceuticals Industry), Journal of Managerial Sciences, Volume VII Number 2 http://www.qurtuba.edu.pk/jms/default_files/JMS/ 7_2/JMS_July_December2013_291-298.pdf

20) Podsakoff. N. P., Lepiine. J. A., 2007, "Differential Challenge-Hindrance Stressor Relationship with Job Attitudes, Turnover Intentions, Turnover and Withdrawal Behaviour: A Meta-Analysis", Journal of Applied Psychology, 92, No.: 2, Pp.: 438-454.

21) Renolds S., 1997, "Psychological Well-being at Work: Is Prevention Better than

22) Cure", Journal of Psychosomatic Research, 43, Рp.: 93-102.

23) Schuler R. S., 1980, "Definition and Conceptualization of stress in Organisation", Organisational Behaviour and Human Performance, pp-189.

24) Selye H., 1956, "The Stress of Life" MacGrowhill, New York, N. Y.

25) Shapiro Shauna L., Schwartz Gary E. and Schwartz Ginny Schwartz, 1998, "Effects of Mindfulness-based Stress Reduction on Medical and Premedical Students." Journal of Behavioural Medicine, Vol.: 21, No.: 6, 1998, Pp.: 1-20.

26) Thomason J. A. and Pond S. B., 1995, "Effects on Instruction on Stress Management Skills and SelfManagement Skills among Blue Polar Employees", in L. R. Murphy, J. L. Hurrel, S. Sauter and G. Keita (Eds.), "Job Stress Interventions", Washington: American Psychological Association.

27) Tucker L, Cole G. and Freedman G., 1986, "Physical Fitness: A Buffer against Stress", Perpetual and Motor Skills, 63, Pp.: 955-961.

28) Williams Stephen, Cooper Cary L., 1998, "Measuring Occupational Stress: Development of Pressure Management Indicator", Journal of Occupational Health Psychology, Vol.: 3, No.: 4, Pp.: 306-321 